IZA DP No. 7470

The Role of University Scientist Mobility for Industrial Innovation

Ann-Kathrine Ejsing

Ulrich Kaiser

Hans Christian Kongsted

Keld Laursen

June 2013 


\title{
The Role of University Scientist Mobility for Industrial Innovation
}

\author{
Ann-Kathrine Ejsing
}

Danish Insurance Association

\author{
Ulrich Kaiser \\ University of Zurich \\ and IZA
}

Hans Christian Kongsted

University of Copenhagen

Keld Laursen

Copenhagen Business School
Discussion Paper No. 7470
June 2013

IZA

P.O. Box 7240

53072 Bonn

Germany

Phone: +49-228-3894-0

Fax: +49-228-3894-180

E-mail: iza@iza.org

Any opinions expressed here are those of the author(s) and not those of IZA. Research published in this series may include views on policy, but the institute itself takes no institutional policy positions. The IZA research network is committed to the IZA Guiding Principles of Research Integrity.

The Institute for the Study of Labor (IZA) in Bonn is a local and virtual international research center and a place of communication between science, politics and business. IZA is an independent nonprofit organization supported by Deutsche Post Foundation. The center is associated with the University of Bonn and offers a stimulating research environment through its international network, workshops and conferences, data service, project support, research visits and doctoral program. IZA engages in (i) original and internationally competitive research in all fields of labor economics, (ii) development of policy concepts, and (iii) dissemination of research results and concepts to the interested public.

IZA Discussion Papers often represent preliminary work and are circulated to encourage discussion. Citation of such a paper should account for its provisional character. A revised version may be available directly from the author. 


\section{ABSTRACT}

\section{The Role of University Scientist Mobility for Industrial Innovation}

Scientific knowledge is an important ingredient in the innovation process. Drawing on the knowledge-based view of the firm and the literature on the relationship between science and technology, this paper scrutinizes the importance of university scientists' mobility for firms' innovative activities. Combining patent data and matched employer-employee data for Danish firms, we can track the labor mobility of R\&D workers from 1999 to 2004. We find that new joiners contribute more than long-term employees to innovative activity in the focal firm. Among new firm recruits, we observe that newly hired former university researchers contribute more to innovative activity than newly hired recent graduates or joiners from firms, but only in firms with a high level of absorptive capacity in the form of recent experience of hiring university researchers. We find also that firms' recent experience of hiring university researchers enhances the effect of newly hired recent graduates' contributions to innovation.

JEL Classification: $\quad 033,034, \mathrm{C} 23$

Keywords: innovative activity, science-technology relationship, labor mobility

Corresponding author:

Ulrich Kaiser

Department of Business Administration

University of Zurich

Plattenstrasse 14

8032 Zurich

Switzerland

E-mail: ulrich.kaiser@business.uzh.ch 


\section{INTRODUCTION}

Search is considered to be local when it involves knowledge that is close to the focal organization's current knowledge base (Helfat, 1994). The advantages to firms that conduct local searches in the course of their problem-solving activities - including problem-solving related to innovation-are well known, and are among the reasons why local search tends to prevail (Fleming \& Sorenson, 2004; Nelson \& Winter, 1982). However, too much reliance on local search could potentially be damaging or fatal for the organization (Levinthal \& Rerup, 2006; Levinthal \& March, 1993; March, 1991; Tripsas \& Gavetti, 2000). An important way for private firms to overcome the local search problem relating to innovation is to use science. The role of science and scientists—or "philosophers and men of speculation" as scientists once were described ${ }^{1}$ - in distant search and consequent innovative activity was noted by Adam Smith as early as 1776 in his Wealth of Nations:

"Many improvements have been made by the ingenuity of the makers of the machines, when to make them became the business of a peculiar trade; and some by that of those who are called philosophers, or men of speculation, whose trade it is not to do anything, but to observe everything, and who, upon that account, are often capable of combining together the powers of the most distant and dissimilar objects in the progress of society..." (Smith, 1976: 10, emphasis added).

Fleming and Sorenson (2004) point out that it was not until the second half of the $20^{\text {th }}$ century that researchers began to test this link empirically, and to develop it further, from a theoretical point of view. An early empirical result in the innovation literature established that successful innovations compared to unsuccessful innovations, show a closer coupling with the scientific and

\footnotetext{
${ }^{1}$ See Pavitt (1991: 110).
} 
technological community in relation to the specific innovation project (Rothwell, Freeman, Jervis, Robertson, \& Townsend, 1974).

Our study is concerned with the role of scientific skill in technological innovation in industrial firms. It is located within two streams of the research literature. The first strand is preoccupied with the role of science (and scientists) in industrial innovation; the second investigates labor mobility among organizational units in the context of innovation. The work within the first strand focuses on how science and university scientists contribute to the innovative efforts of private business firms (e.g., Cockburn \& Henderson, 1998; Fleming \& Sorenson, 2004; Gibbons \& Johnston, 1974; Gittelman, 2007; Jaffe, 1989; Liebeskind, Oliver, Zucker, \& Brewer, 1996; Spencer, 2001). Within this body of work, Jaffe (1989), in a study of the extent of research and development (R\&D) knowledge flows at US state level finds that corporate patenting responds positively to knowledge from academic research, providing evidence of the importance of geographical proximity for shaping the patterns of university-industry interaction. This suggests that the co-location of complementary resources may increase the opportunities for commercialization. Fleming and Sorenson (2004) point to the advantages of scientific thinking in technological search. They show that patents are more frequently cited if they contain references to scientific papers, and if the frequency of the patent subclasses that appear in combination with other subclasses, in other patents, is high (the authors describe this as "coupling"). In the context of high levels of coupling, Fleming and Sorenson argue that scientific knowledge and methods can serve as a "map" that helps to structure the search process more systematically. Along these lines, Gittelman (2006) finds that patents whose development involved scientists who had worked in a public lab before later joining a biotechnology firm, receive more citations than other patents. 
The second strand in the literature focuses on labor mobility as a source of knowledge spillovers for innovative activity (e.g., Almeida \& Kogut, 1999; Corredoira \& Rosenkopf, 2010; Kaiser, Kongsted, \& Rønde, 2011; Rosenkopf \& Almeida, 2003; Singh \& Agrawal, 2011; Song, Almeida, \& Wu, 2003; Tzabbar, 2009). For example, Rosenkopf and Almeida (2003) examine pairs of firms and show that dyads involved in high levels of mutual labor mobility are involved also in greater knowledge flows. As a consequence, inter-firm collaboration through alliances, combined with inter-firm labor mobility, might help to overcome the local search problem referred to above. Also, Tzabbar (2009) shows that the recruitment of technologically distant scientists is positively related to firm-level technological repositioning. In a paper that uses the Danish register data employed in our study, Kaiser, Kongsted and Rønde (2011) study the mobility of workers across private sector employers. They find that workers who transfer to a new firm from a previous employer that was involved in patenting, contribute substantially to their new employers' patenting activity. They contribute more than joiners from non-patenting firms, or non-mobile workers. Their main finding, however, is that workers who leave to join a firm that patents, appear also to contribute to the patenting activity of their previous employer. They also promote stronger cross-citation between the two firms.

While both these streams of research have produced important insights, they have some major limitations. The contributions in the first stream do not explicitly model the mechanisms by which industrial firms gain access to academic science and/or do not analyze how this access affects firm-level outcomes. The second group of work does explicitly model a mechanism (labor mobility), but typically looks at hirings from other industrial firms but not from universities. It looks also at how labor mobility affects the hiring firms' technological search processes (reflected in patent citations), not their innovative output. Lastly, this literature relies 
predominantly on patent data for measuring R\&D worker mobility. This implies that only individual inventors whose names appear on patents registered before and after a move will count as mobile.

The present study should help to fill some of these gaps. It analyzes the effect on private sector firm-level innovation of recruiting R\&D workers from universities, controlling for and comparing the inward mobility of labor from other types of organizations. To our knowledge, this is the first paper to study this effect. Empirically, we can trace the mobility of all R\&D workers in an entire economy and not just that of persons named on patents, before and after a move. The paper draws on the knowledge-based view of the firm and the literature on the relationship between science and innovation, to examine the importance of mobility of university scientists for firms' innovative activities. Using these elements, we build a theory whose basic proposition is that firms' hirings of university researchers can provide important support for boundary-spanning search that leads to more firm-level innovation. However, while university scientists often interact with private firms on the basis of aligned economic interests, they operate under very different incentive systems which reward the disclosure rather than the exploitation of knowledge (Breschi, Lissoni, \& Montobbio, 2008; Dasgupta \& David, 1994; Gittelman \& Kogut, 2003). Therefore, there are significant initial costs involved in hiring university scientists. For this reasons we hypothesize that absorptive capacity, represented by experience of hiring university scientists in the past, is central to achieving benefit from this type of recruitment.

We use a unique register data set on the entire population of Danish firms and their employees, for the period 1999 to 2004 . These data allow us to measure the average innovation effects of public R\&D workers moving to private firms. We link these data to the number of each 
individual firm's patent applications to the European Patent Office (EPO); this is our measure of innovation. The analysis focuses on firms that employ at least one R\&D worker, since these firms are more likely to patent. It is based on 16,531 observations for 5,714 firms. The econometric analysis takes account of state dependence-past innovative activity is likely to have an impact on present innovation, and also unobserved firm-specific time-invariant heterogeneity—some firms may be inherently better at innovating than others, perhaps because of better management of $R \& D$. We investigate the extent to which science or engineering graduates who join a private firm following employment as a university researcher after graduation ("joiners from universities"), contribute to the innovative output of the firm they join. We also consider the effects of recent science or engineering graduates who enter the private sector after graduation ("recent graduate joiners"). We contrast these impacts with the effects of R\&D workers who either worked in another firm ("joiners from firms") or have been employed only by the focal firm ("stayers"). In line with the literature, we find that firm joiners contribute more than stayers to innovative activity, that is, in the context of innovation, firms can engage in explorative learning through inward mobility of researchers. More importantly, we find that newly hired university researchers make a bigger contribution to innovative activity than newly hired recent graduates or joiners from other firms, but only if the hiring firm has recent experience of hiring university researchers. In addition, we find that firms' recent experience of hiring university researchers enhances the effect of newly hired recent graduates' contributions to innovative activity.

\section{EMPIRICAL AND THEORETICAL BACKGROUND}

There is a long tradition in innovation studies (Fleming \& Sorenson, 2004; Kogut \& Zander, 1992; Nelson \& Winter, 1982; Schumpeter, 1912/1934) that proposes that innovation can be 
conceptualized as resulting from the novel integration of previously separate bodies of knowledge that have commercial application. The knowledge-based view posits that a firm's competitive advantage depends on its ability to combine initially separate knowledge and to recombine the resulting new knowledge to produce innovations, through a learning process that depends on the level of the given firm's "combinative capabilities" to synthesize and apply current (firm-internal) and acquired (external) knowledge (Kogut \& Zander, 1992). We build on this approach and examine the ability of firms to create new knowledge by recombining recombination knowledge from across organizational boundaries, i.e. combining their existing knowledge with new knowledge acquired via worker mobility. We focus particularly on the knowledge reconfiguration capabilities of firms by examining the inward mobility of university scientists.

Our analysis starts from the premise that human capital is mobile since employees generally are free to quit and take up a new job at will, and that they carry with them some parts of the knowledge developed at the previous employer (Agarwal, Echambadi, Franco, \& Sarkar, 2004; Campbell, Ganco, Franco, \& Agarwal, 2012; Liebeskind, 1997). We assume also that some university scientists and other R\&D workers are willing/able to move. The reasons commonly cited for university scientists moving to employment in industry are higher salaries, and in some cases, better research funding opportunities (see e.g., Agarwal \& Ohyama, 2012; Roach \& Sauermann, 2010), although the reasons for a move are not a central concern of the present paper.

We adopt Nelson and Rosenberg's (1994) view that universities conduct mostly basic research, aimed at understanding phenomena at a relatively fundamental level, although this is not to imply that such research is unaffected by the pull of important technological problems and 
objectives. Nelson and Rosenberg (1994) suggest that the major share of industry R\&D is aimed at shorter term problem-solving, design and development. Because the payoffs are more immediate and easier to appropriate than those from basic research, industry performs very little basic research and undertakes relatively little training of scientists in research skills. Since science is concerned mostly with explorative learning, firms often find academic science and scientific skills extremely useful complements to their internal capabilities when working on innovations. However, as we describe below, these more academic skills can be problematic for profit-motivated firms.

\section{HYPOTHESES}

\section{Boundary-spanning through general labor mobility}

Our first hypothesis can be considered a "baseline hypothesis". It corresponds with what is implied in the innovation and labor mobility literature (Rosenkopf \& Almeida, 2003; Singh \& Agrawal, 2011; Song et al., 2003), although this literature focuses on the effect of mobility on knowledge flows, and not on the level of innovative activity, the focus of the present paper. Innovative activities are largely firm-specific, local and cumulative, making inter-organizational transfer of useful knowledge difficult (Dosi, 1988; Szulanski, 1996). However, as Dosi (1988: 1131) notes, "People can be hired away from one firm to another", enabling the transfer of the skills and tacit knowledge related to innovation.

The innovation literature (Cantwell, 1989; Helfat, 1994; Pavitt, 1988; Stuart \& Podolny, 1996; Tripsas \& Gavetti, 2000) suggests that initially, the organizational members should search for innovative solutions related to new processes, products, and services in areas where the organization already has expertise. Nelson and Winter (1982: 9-10) refer to organizations being "typically much better at the tasks of self-maintenance in a constant environment than they are at 
major change, and much better at doing 'more of the same' than they are at any other kind of change". In other words, learning is easier if it is related to the familiar (Cohen \& Levinthal, 1990). The problem with firm-internal ("local") sources of inputs to the innovation process is that - on their own — they tend to provide limited inspiration and variety for resolving innovation-related problems; the local search environment is narrow in terms of opportunities for the combination and recombination of knowledge (Chesbrough, 2003; Fleming \& Sorenson, 2004; Laursen \& Salter, 2006; Rosenkopf \& Nerkar, 2001; Rothaermel \& Alexandre, 2009). Our definition of innovation involves the novel integration of previously separate bodies of knowledge, thus the availability of variety is central (Metcalfe, 1994). In-house sources of knowledge variety, by definition, are limited but beyond the boundaries of the focal organization are numerous sources. In the context of $\mathrm{R} \& \mathrm{D}$ worker mobility, inward mobility-regardless of origin-provides the hiring firm with access to parts of the previous employer's organizational routines and knowledge bases, which most likely are different from those of the focal firm. These internal and external elements can often be fruitfully recombined to produce innovation (Kogut \& Zander, 1992). In sum, we hypothesize that:

Hypothesis 1: Joiners contribute more to innovative activity than firm stayers.

\section{The benefits of hiring university scientists for innovative activity}

The literature on the role of academic science for industry innovation identifies several benefits (see, Pavitt, 1991; Salter \& Martin, 2001). They can be obtained through the hiring of human capital (university researchers) which arguably is an important channel for the transmission of science: knowledge transfers in the context of the links between basic science and technology "are mainly person-embodied, involving personal contacts, movements, and participation in national and international networks" (Pavitt, 1991: 112). We can distinguish 
three major benefits from employing former academic scientists: 1) their direct and important role in technological problem-solving, based on their scientific knowledge; 2) their access to networks within the university system, which contributes to their technological problem-solving activities; and 3) their application of general scientific research skills and techniques to technological problems. Note that these benefits overlap, but for analytical reasons we consider them as separate.

Nelson and Rosenberg suggest that since science is basically concerned with explorative learning, scientific knowledge is often directly useful for technological problem-solving in private firms. For instance, the general principle related to a pharmaceutical drug may be scientific knowledge, but the artifact only becomes a commercial product after a process in which scientific and technological knowledge interact. In other words, there are often complementarities between scientific and technological knowledge utilized by private firms (Agarwal \& Ohyama, 2012).

In this context, Gibbons and Johnston (1974) found that scientists were particularly critical for "translating" information from scientific journals into a form that was meaningful to industry problem-solvers. Former university scientists also are able to draw on social networks in the university system to help their technological problem-solving activities. One of the respondents in Gibbons and Johnston's (1974: 238) study noted that:

Whenever we had a knotty problem I knew I could always go up to the uni (sic) and talk it over with the electronics people I knew from the old days, and what's more use their equipment and library. I kept this quiet and I got a reputation as the man to see with a difficult problem. 
Former university scientists are also able to draw on international networks of colleagues and co-authors, which increases the awareness of their employers of the leading scientists in relevant fields and their scientific resources (Murray, 2004).

The third advantage is that former university scientists are able to apply their general research skills and techniques to technological problems. Gibbons and Johnston (1974) found that scientists presented with a problem may be able to provide a direct solution, but more often will suggest alternative ways of tackling it to reduce the range of possibilities, or access equipment and procedures to test the feasibility of a solution. At a more general level, Fleming and Sorenson (2004) argue that scientific knowledge can lead to other types of searches than local technological search, by providing inventors with "map" or a stylized representation of the area to be searched. Scientific knowledge differs from knowledge derived from technological practice because scientific activity most often involves the generation and testing of theories. Fleming and Sorenson (2004) show that science attempts to explain the occurrence of phenomena, and suggest means for predicting the results of experiments and the usefulness of new configurations of technological components. An understanding (or map) of the fundamental problem, can alter the inventor's search process, leading more directly to useful combinations and eliminating fruitless research directions, and by motivating them to persevere even in the face of negative results.

We argue that, given the potentially major benefits to firms of combining scientific knowledge, skills and techniques with technological problem-solving activities, hiring university scientists compared to recruiting recent graduates and joiners from other firms will have a stronger effect on innovation activity. Recent graduates have less scientific experience and less involvement in scientific networks than former university researchers, and thus have less 
"science" to offer the firm. Joiners from other firms are likely to contribute knowledge, skills and techniques that are mostly similar to those owned by the focal firm. Song et al. (2003) note, that researchers hired from other firms are likely to exhibit local search behaviors and attempt to innovate in technological areas close to their existing knowledge (i.e. the previous firm's knowledge). These arguments suggest that:

Hypothesis 2: Newly hired university researchers make a larger contribution to innovative activity than newly hired recent graduates or joiners from other firms.

\section{The costs of hiring scientists: Investments in absorptive capacity}

While the benefits to firms from science and recruitment of university scientists are evident, hiring scientists implies some non-trivial costs for the recruiting firm (additional to the usual cost of new hires). These non-trivial costs include the difficulty of integrating university scientists into the firm's local knowledge production. The costs involved in crossing the boundary between science and technology are related to fundamental differences in the structure of knowledge production in these spheres. Science and technology are similar in that they use similar inputs (scientists, engineers, laboratories) and produce similar outputs (knowledge) (Pavitt, 1991) and there are some famous examples of exceptional science being performed in the laboratories of large industrial firms (Rosenberg, 1990). However, Pavitt (1991) highlights that these observations overlook the very different nature and purpose of the core activities of university and business laboratories.

According to Dasgupta and David (1994), the fundamental differences between scientific and technological knowledge are the nature of the goals, the norms of behavior (especially regarding the disclosure of knowledge) and the reward systems that are considered legitimate by the two communities of researchers. Based on these goals, norms and incentives, academically trained 
scientists tend to have a strong "taste for science" including a preference for basic research, the freedom to choose among research projects, and disclosure of research results through publications (Agarwal \& Ohyama, 2012; Roach \& Sauermann, 2010; Stern, 2004). It should be noted, however, that industry-employed scientists tend to have a stronger preference for pay and a relatively weaker preference for academic freedom when compared to university scientists (Sauermann \& Stephan, 2012). Also, while industry may often need scientific insights to resolve technological problems or to identify new ideas, firms do not gain directly from contributing to important scientific questions (Gittelman \& Kogut, 2003; Lacetera, 2009). These observations suggest that employment of former university scientists may be challenging for profit-oriented business firms.

Firms often respond by allowing employees from academia to have involvement in activities such as publishing (Cockburn \& Henderson, 1998; Ding, 2011; Roach \& Sauermann, 2010; Rosenberg, 1990). Nevertheless, integrating individual scientists into the innovative activities of for-profit firms can be difficult and can produce tensions. It is necessary to have a deliberate strategy involving a laborious process of learning in order to exploit these potentially valuable knowledge inputs. In our setting this means firms need a certain level of absorptive capacity in order to assimilate university scientists and integrate the important knowledge and skills they confer. Cohen and Levinthal (1990: 128) argue that a firms' absorptive capacity is "largely a function of the level of prior related knowledge." We use this argument to support the idea that firms with experience of recruiting university scientists will be more likely and more keen to accommodate these scientists and will have learnt how to integrate them in the firm's knowledge production activity. They will be able to cope with employees unaccustomed to the goals, norms and incentives of for-profit organizations. 
In addition to the learning effect, experience of employing former university scientists is a signal to university scientists with a real "taste for science" that the firm in question will allow their continued involvement in academic activities. Employees with a university science background can help identify potential recruits and inform potential candidates about the firm's “science strategy" and work conditions (Ding, 2011). It is particularly important for private firms to be able to hire scientists who have a degree of "taste for science" as such a taste is a necessary condition for individual scientist's being able to offer the state-of-the-art scientific skills and knowledge that will benefit industrial innovation. In sum, we hypothesize that:

Hypothesis 3: Firms' recent experience of hiring university researchers enhances the effect of the newly hired university researchers' contributions to innovative activity.

\section{Hiring experience and recent graduates}

In their review of the literature on the economic benefits of publicly funded basic research, Salter and Martin (2001: 522), conclude that "[m]any studies of the economic benefits of publicly funded research identify skilled graduates as the primary benefit that flows to firms" because new graduates entering industry bring knowledge about recent scientific research as well as scientific skills and techniques. It is inevitable that recent graduates will have less scientific experience and will be less deeply embedded in scientific networks. These factors are less important if the hiring firm already employs former university scientists because they can help train these recent graduate recruits and introduce them to their professional scientific networks. The inclusion on firm staff of former university researchers will attract recent graduates with a bent for science, while ex-academic scientists can help to identify new graduates with the relevant scientific knowledge, skills and techniques among potential recruits to industry. In 
summary, we suggest that a complementary relationship exists between industrial firms' recent experience of hiring university researchers and their recruitment of recent graduates:

Hypothesis 4: Firms' recent hiring of university researchers enhances the contribution to innovative activity of newly recruited recent graduates.

\section{METHODS}

\section{Data}

Patent data. The first set of data is all patent applications filed with the EPO since 1978 (when the EPO was established) with at least one Danish applicant. These data are taken from the EPO's PatStat ("Worldwide Patent Statistical Database"). This data set is critical since our measure of innovation is patent counts. Although patent counts clearly are imperfect proxies for real innovative activity (Arundel \& Kabla, 1998), they provide a proxy for the intermediary output, R\&D; are representative of a specific invention (patent applications refer to single inventions); and can be related to patent value correlates (Trajtenberg, 1990). Patent counts are used extensively in the management (Almeida \& Kogut, 1999; Song et al., 2003; Stuart \& Podolny, 1996) and economics literature (Blundell, Griffith, \& van Reenen, 1995; Griliches, 1990; Kim \& Marschke, 2005). Our data end in 2004 due to reporting lags at the EPO.

Matched employer-employee data. We use matched employer-employee information provided by Statistics Denmark: our data set includes the whole population of Danish firms and workers, not a selected sample. The database is a recognized and valuable resource for research in the social sciences (see for instance, Dahl, 2011; Sørensen, 2007, as recent examples of applications of these data). Matched employer-employee data are available from 1980. Information on the firm-level variables is available from 1999. A structural break in the recording of the unique firm identifiers used by Statistics Denmark prevents us from using pre1999 information. 
To create our data set we matched the unique firm identifiers from the firm-level data, with each of the patent applicants in our patent data. We achieved a matching for 95 percent of the applicants. The unmatched ones are firms that exited before 1999, and would have been excluded because our firm-level information begins only in 1999. Since current patent counts are the result of past research efforts, we lag all R\&D-related variables by one period as in Blundell et al. (1999). Therefore the effective starting date of the within-sample period is $2000 ; 1978-99$ is a pre-sample period of information on patents used in the estimation (see below).

Firm identifier numbers make it straightforward to match patent application and firm-level data, which essentially contains balance sheet information. Finally we matched these data to our employee-level data, which provides information on the highest level of education attained by the individual worker, and details of current occupation. We use this information to define our population of $\mathrm{R} \& \mathrm{D}$ workers. The employee-level data were aggregated to the firm level before being merged, i.e. our estimations consider the total number of R\&D workers in each firm.

We do not consider the whole population of firms since firms with no R\&D workers are unlikely to patent (see the findings in Kaiser, Kongsted, \& Rønde, 2008, using similar data). Therefore the final data set is subject to the following restrictions: first, data are for firms with at least one R\&D worker. R\&D workers are defined as individuals aged between 20 and 75 , with a master's or $\mathrm{PhD}$ degree in technical sciences, natural sciences, veterinary sciences, agricultural sciences or health sciences, occupying a job function that requires a "high" (professionals) or "intermediate" (technicians and associate professionals) level of skills. ${ }^{2}$ Second, we include only

\footnotetext{
${ }^{2}$ The information on job function skill levels was retrieved from the International Standard Classification of Occupations (ISCO) published by the International Labor Office, at http://www.ilo.org/public/english/bureau/stat/isco/isco88/publ4.htm
} 
private sector firms (although we consider labor mobility from the public sector). The main estimation results are based on 16,531 firm-year observations of 5,714 unique R\&D active firms. A total of 292 different firms patented at least once within the five years 2000-2004.

Dependent Variable. Our dependent variable is number of patent applications by firm $i$ in year $t$. In order to account for the skewed patent value distribution (Hall, Jaffe, \& Trajtenberg, 2005; Harhoff, Narin, Scherer, \& Vopel, 1999; Lanjouw, Pakes, \& Putnam, 1998), we weight each patent application by the number of citations received by the patent. More specifically, and following Trajtenberg (1990), we weight each patent by 1 plus the number of citations to the patent within the three-years following the year of EPO publication. ${ }^{3}$

Independent variables. We separate the population of $\mathrm{R} \& \mathrm{D}$ workers into knowledge-intensive $R \& D$ workers and $R \& D$ support workers according to the level of skills required in their current occupation. The first group includes people in positions requiring high levels of scientific and technological activity, who are the focus of this analysis. The second group defines workers in positions requiring an intermediate level of scientific and technological activity, or R\&D support workers, which are included in our estimations as control variables. We further differentiate among knowledge-intensive R\&D workers according to mobility status. We identify movement between non-affiliated firms, and between universities and firms. The types of workers considered are: (i) Stayers who are employed in firm A at time $t$ and time $t$-1; (ii) Joiners from firms who are workers employed in firm A at time $t$, but are employed in firm B at time $t$-1; (iii) Joiners from universities, defined as workers employed in firm A at time $t$ and at a university at

\footnotetext{
${ }^{3}$ A 5-year time window is common; we chose a shorter time because our citation data end less than 4 years after the patent data. Our patent citation data are from the "EPO/OECD patent citations database", available from the OECD (Webb, Dernis, Harhoff, \& Hoisl, 2005) and cover the period 1978-2006.
} 
time $t-1$; (iv) Recent graduate joiners are defined thus irrespective of their previous employment status and according only to time since graduation: They acquired their R\&D-related education in $t-1$ and were employed in a knowledge-intensive position in firm A at time $t$; ; and (v) Other joiners who are employed in firm A at time $t$ and whose employment status at $t-1$ is unknown. ${ }^{4}$ Having defined all the relevant worker types, the employer-employee link is used to aggregate the information at firm-level, and then to determine the share of each R\&D worker type for each firm.

We control also for a set of variables conventionally considered to be determinants of patent activity. First, we include the natural logarithm of the total number of $R \& D$ workers- $\ln (R \& D$ workers). Second, we include capital stock, measured as the book value of physical capital$\ln$ (capital stock). Third, we control for firm openness to cooperate with other entities using a dummy variable that is coded 1 if the firm has co-patented with another legally independent firm—Previous cooperation and zero otherwise. We checked manually (on websites) for legal independence of respective international co-patentees because our data refer only to Danish firms. Fourth, we include a dummy variable for openness defined as co-patenting with a public sector entity-Previous cooperation with public sector. Most public-private research endeavors in Denmark are set up via a network of nine independent research and technology organizations which account for most public sector co-patentees. Fifth, we include a set of sector dummies defined according to the two-digit NACE Rev.1 industry classification, and we control for regional effects and time-fixed effects using dummy variables. Finally, we account for unobserved permanent firm heterogeneity and state dependence as described below.

\footnotetext{
${ }^{4}$ These are persons who previously were self-employed, were on leave of absence schemes, or entered the country (immigrants) between $t-1$ and $t$.
} 


\section{Model Specification and Estimation}

The patent production function. We assume a Cobb-Douglas knowledge production function (Blundell et al., 1995; Hausman, Hall, \& Griliches, 1984). Patent output $P$ depends on labor input $L$, capital input $K$ and a term $A$ that captures a set of additional control variables. Labor input is split into joiners from firms, $L_{J}$, joiners from university research, $L_{U}$, recent graduates, $L_{G}$, other joiners, $L_{O}$, stayers, $L_{S}$ and support workers, $L_{P} ; L=L_{J}+L_{U}+L_{G}+L_{O}+L_{S}+L_{P}$. The six types of R\&D labor enter the patent production function as efficiency units, as in Hellerstein et al. (1999) and Galindo-Rueda and Haskel (2005). This enables us to estimate each labor type's relative patent productivity. We normalize the marginal patent productivity of each labor type by the marginal patent productivity of stayers, $L_{S}$, and use natural logarithms to obtain:

$$
\ln P=\ln A+\beta \ln K+\alpha \ln L+\delta_{J} S_{J}+\delta_{U} S_{U}+\delta_{G} s_{G}+\delta_{O} s_{O}+\delta_{P} S_{P},
$$

where $s_{k}$ denotes the share of labor type $k, s_{k}=L_{k} / L$, and stayers are the omitted reference category.

Count data models. The dependent variable is discrete and takes the values zero or a positive integer, making a count data model appropriate. The most popular count data model is Poisson regression (Cameron \& Trivedi, 1986; Winkelmann, 2008) with an exponential mean function, as applied in Hausman et al. (1984). However, the Poisson model assumes equality between conditional mean and conditional variance, i.e., equi-dispersion. This assumption is often violated when using patent data (Blundell et al., 1995; Cincera, 1997). We chose the Negative Binomial model which allows for a more flexible relationship between mean and variance and for over-dispersion in the data. Tests for equality of mean and variance also favor the Negative Binomial model over the Poisson model. 
Unobserved heterogeneity. Our specification controls for firm-specific permanent heterogeneity in patenting activity, e.g.,, due to differences in $R \& D$ management, different $R \& D$ investment appropriability conditions, or different technological opportunities. There are two commonly used ways to deal with this problem: fixed effects and random effects models. Random effects are not plausible in our setting since unobserved permanent heterogeneity most likely will be correlated with the regressors. Blundell et al. $(1995 ; 1999)$ suggest fixed effects to proxy for unobserved permanent heterogeneity. Their "pre-sample mean estimator" is developed for count data models where the information on the dependent variable covers a longer period than the information on the explanatory variables. This applies to our data: the patent data start in 1978; the firm-level information (allowing for lags) starts in 2000. The estimator uses the average of the dependent variable over the pre-sample period as a proxy for correlated fixed effects (for each firm). Hence the key assumption here is that the main source of unobserved permanent heterogeneity in patent productivity is the pre-sample patent stock.

The pre-sample mean estimator relies on the stationarity of the dependent variable. Since there is a strong upward trend in the number of patent applications, we apply a trend adjustment to the proxy variable as suggested by Kaiser et al. (2008). In our practical implementation of the fixed effects proxy variable, we follow Blundell et al. $(1995 ; 2002 ; 1999)$ and include the natural logarithm of the pre-sample mean number of patent applications per firm. For firms with no presample patent applications, we substitute an arbitrary small constant as in Blundell et al. (1999). To account for this non-linear transformation and for the patent count being 0 for most firms, we include a dummy variable coded 1 if the firm has at least one pre-sample patent and 0 otherwise.

State dependence. We control for possible state dependence in patenting activity. Blundell et al. (1995) include firm $i$ 's discounted patent stock as an explanatory variable. However, we 
follow the approach in Crépon and Duguet (1997) and introduce state dependence by including a dummy variable for patenting activity in $t-1$, since this emphasizes recent patenting activity and circumvents collinearity problems by using fixed effects proxy variables.

\section{RESULTS}

Table 1 presents the firm level descriptive statistics for the dependent and explanatory variables. It differentiates between firms with pre-sample patents, i.e., firms with at least one patent application before 1999, and firms with no pre-sample patent applications. Stayers (63.1\%) constitute by far the largest group of $\mathrm{R} \& \mathrm{D}$ workers among current $\mathrm{R} \& \mathrm{D}$ employment, followed by support workers $(16.1 \%)$, and joiners from the private sector (11.5\%). Other joiners, and recent graduates account for about 4 percent each of the R\&D workforce, while joiners from university research constitute the smallest employment category at 0.8 percent of all $R \& D$ workers. In our data, the average firm employs about seven $R \& D$ workers; firms with patenting activity prior to 1999 employ 21 R\&D workers; and firms without pre-sample patents employ about 5 R\&D workers.

\section{[Insert Table 1 about here]}

Table 2 consists of a correlation matrix of our explanatory variables. It shows that the correlation between variables is low, confirmed by a mean variance inflation factor (VIF) of 1.67, which is well below the critical value of 10 suggested by Belsley et al. (1980).

[Insert Table 2 about here]

Table 3 presents our estimation results. Note that the coefficient estimates corresponding to $\mathrm{R} \& \mathrm{D}$ worker shares do not directly translate into marginal effects, as in ordinary least square (OLS) models. However the signs are directly interpretable. For example, a positive coefficient of any of the five $R \& D$ worker group shares included in the estimation indicates that the respective worker group contributes more to innovation than $R \& D$ stayers, the comparison 
group.

Hypotheses 1 and 2 imply multiple comparisons, so we conduct tests for joint significance. Hypothesis 1 refers to three types of joiners (firm joiners, university researchers, university graduates) whose effect on patenting is compared to the contribution of stayers. We test separately for each of these mobile labor types' contributions to patenting compared to that of stayers, and apply joint tests for firm joiners, university researchers and university graduates contributing more than stayers. The results for the joint significance tests and the findings related to Hypothesis 2 (comparing university researchers with firm joiners and also with university graduates) are presented in Table 4.

[Insert Table 3 about here]

Hypothesis 1 states that joiners (of any type) contribute more to innovative activity than stayers. Table 3 Model I shows that the effects of joiners from firms, other joiners and university researchers are all positive and significantly different from the effect of stayers on innovative output, but that the effects of graduate joiners and support workers are not. When we look at the joint effect (stayers vs. the three different types of joiners-see Table 4), we find clear support for our hypothesis because the joint test is significant at the 1 percent level. The results are also consistent with Hypothesis 2 that newly hired university researchers contribute more to innovative activity than newly hired recent graduates or joiners from (other) firms. First, the coefficient of the share of university researchers is large, and significant at the 1 percent level (see Table 3, Model I). Second, the joint test for the effect of hiring university researchers compared to the effects of newly hired recent graduates and joiners from firms is significant at the 5 percent level (see Table 4).

[Insert Table 4 about here] 
Hypotheses 3 and 4 refer to firm $j$ having hired a university researcher in the recent past. Recent experience in hiring university researchers is defined as hiring by firm $j$ at $t-2$. To test Hypothesis 3 we interact this dummy variable with the share of university researchers firm $j$ hired at $t$. To test Hypothesis 4 we interact the dummy variable for past experience of hiring university researchers with the share of recent graduates. We find support for Hypothesis 3 that recent experience of hiring a university researcher enhances the contribution of new university recruits to innovative activity. Table 3, Model II, shows that the effect of the share of newly hired university researchers at $t-1$ interacted with the share of recently hired university researchers at $t-2$ is positive and significant at the 5 percent level. Note that the main effect of newly hired university researchers at $t-1$, disappears when the interaction term is inserted into the regression. Thus absorptive capacity matters. Hypothesis 4 proposed that experience of hiring university researchers enhances the contribution of newly hired recent graduates to innovative activity. Our results provide strong support for this hypothesis: the interaction effect of newly hired recent graduates and the share of hired university researchers at $t-2$ is positive and statistically highly significant. In contrast, in Model II the coefficient of (non-interacted) graduate joiners is statistically insignificant. This indicates that only firms with experience of hiring university researchers are able to benefit from current hiring of university graduates, which highlights the importance of absorptive capacity.

Table 5 presents the marginal effects. Marginal effects provide information on the absolute change in the expected number of patent applications due to an increase of one in the number of workers from a particular skill group. Marginal effects are linearly dependent on the number of the firm's patent applications, which implies that marginal effects are 0 if the firm did not apply for a patent. Table 5 presents the marginal effects across (i) all firms, (ii) firms with patents in 
the period under consideration, and (iii) firms with pre-sample patents. We present marginal effects also for the average firm had it applied for a patent (the same calculation as in (i) but with exactly 1 patent "artificially" assigned to each firm).

[Insert Table 5 about here]

Starting with the specification with no interaction, Table 5 shows that university joiners make the largest contribution to firms' patenting. Across all firms, one additional university researcher leads to 0.09 additional patents. The effect is substantially larger for firms with pre-sample patents (0.20); for firms with a patent in the period under consideration (0.35); and the average firm with one patent (0.29). Both firm joiners and graduate joiners add 0.04 new patents; there is no statistically significant difference between these two types of workers. The marginal effect for support workers is 0.02 . The marginal effects are statistically insignificant for other joiners and R\&D stayers.

The marginal effects for the specification with the interaction for previous hires of university researchers confirms our finding about the importance of past hires for innovation. Table 5 shows that the marginal effect of university researchers is 0.20 -five additional workers generate one additional patent for firms with experience of university researcher hires (across all observations). For the average firm with one patent and past university researcher hires, the marginal effect is 0.53 ; i.e., two additional workers generate one additional patent. In contrast, the marginal effect of recruiting a university researcher is statistically insignificant for firms with no experience of hiring university researchers. We find similar results for recent university graduates. The marginal effect is 0.15 for firms with past university researcher hires and substantially larger than the effect for firm joiners at 0.03 . However, firm joiners is the only 
group that statistically significantly adds to the patenting activity of firms without university researcher hires. The marginal effect is 0.05 for this type of worker across all firms.

\section{ALTERNATIVE EXPLANATIONS AND ROBUSTNESS CHECKS}

In this section we discuss whether there may be other factors driving our estimation results, and run alternative models to check whether our results hold in different settings. For reasons of space the estimations and results are not presented here. Alternative explanations for our results include differences in experience and education among worker groups. Mobile workers might be more experienced and better educated than non-mobile workers (related to Hypothesis 1), and this might be true also of joiners from university research versus recent graduates and joiners from other firms (related to Hypothesis 2). This might be an alternative explanation for our empirical results. However, inspection of our data lends additional support to Hypothesis 1: mobile workers tend to be less experienced and less well educated than their stayer peers, and this holds also for recent graduates and joiners from firms.

When comparing joiners from university research and recent graduates, as expected, we find clear differences in experience and formal education levels. However, both these differences can be regarded as integral to the predicted differences in the amount and quality of the scientific and technical human capital accumulated by workers in either group; thus our descriptive findings are consistent with Hypothesis 2. In relation to the timing of moves between academe and industry it seems that most moves out of university employment are the result of unfavorable tenure decisions, and therefore work against the effect of positive selection after graduation.

We observe also that firm joiners on average are more experienced than joiners from university research. This effect would tend to offset our results and hence reinforces our interpretation based on the theoretical model. Education levels are higher among joiners from 
university research, which is consistent with our interpretation that the differential effect between joiners from university research and firm joiners is driven by the better ability of university scientists to re-combine scientific skills and techniques and by access to useful social networks. These considerations support Hypothesis 2. A final alternative explanation for our findings might be that university researchers and university graduates tend to want to participate in patentintensive sectors. However, our data show that this is not the case. These alternative explanations tend to reinforce our actual findings.

We conducted robustness checks for whether not applying citation weighting changes the findings. The results of the main model in Table 3 are fully supported when citation weights are not applied to our dependent variable although the corresponding coefficient estimates and marginal effects are slightly smaller compared to the specification with citation weights. Finally, we analyzed to what extent very patenting active firms-possibly very relevant in a small economy such as Denmark-and the chemicals sector (which includes biotechnology) which is a particularly patent active sector, matter for the results. We found that neither the exclusion of neither very patenting active firms nor firms in the chemicals industry substantially affects our estimation results for the baseline model. However, the corresponding coefficient estimates and the marginal effects are smaller than for the full data.

\section{CONCLUDING DISCUSSION}

This paper started from the proposition that firms' hiring of university researchers can provide important support for boundary-spanning search which leads to more firm-level innovation. Our empirical approach took account of state dependence and unobserved firm-specific timeinvariant heterogeneity. We found support for the general idea that inward mobility of researchers has a positive effect on the level of innovative activities in private business firms. More specifically, we demonstrated that newly hired university researchers play a greater role in 
affecting innovative activity than newly hired recent graduates or joiners from firms, but only if the hiring firms have recent experience of recruiting university researchers. We observed also that firms' recent experience of hiring university researchers enhances the effect of newly hired recent graduates' contributions to innovative activity.

Our study adds to the existing research. First, we contribute by extending the theoretical and empirical underpinnings of the resource-based view (RBV) of the firm. The RBV suggests that variations in investment choices over resources, drive variations in firm performance. However, the RBV provides little information on how firms identify opportunities and make ex-ante investments that become valuable ex-post. Although proponents of the RBV acknowledge that recruitment from outside may enable firms to overcome the constraints on firm growth imposed by internal resources and capabilities (Barney, 1991; Penrose, 1959), the theory does not explain how such recruitment helps to generate innovation and value. The knowledge-based view can be considered an extension of the RBV. It states that a firm's competitive advantage depends on its ability to combine previously separate bodies of knowledge, however, it is not precise about how these elements should be combined to create this competitive advantage. Although we do not provide complete solutions, we make a contribution by providing a set of micro mechanisms that underpin how newly recruited human capital in the form of university scientists can provide important inputs to the innovation process in private business firms.

We contribute also to the organizational learning literature (Levinthal \& March, 1993; Rosenkopf \& Nerkar, 2001) by establishing theoretically—and corroborating empirically-that recruiting university researchers is an important way to overcome local search problems at firm level. We also explicitly address the important costs of this boundary-spanning search. Empirically, we found only positive effects from hiring recent graduates and university 
researchers provided that the focal firm has some experience of hiring university researchers: in line with the idea proposed by Cohen and Levinthal (1990) and Rosenberg (1990) in the context of private firms' absorptive capacity, knowledge is not a public good and its absorption requires substantial and specific investment. It should be noted that the effect of absorptive capacity is likely to have been underestimated in our results. It is possible that the positive effect of hiring the first university scientist will be potentially higher than the effect derived from hiring the $n^{\text {th }}$ scientist, given the high potential for knowledge recombination. Other things being equal, this would imply a negative interaction effect of newly hired university researchers at $t$ - 1 interacted with the share of recently hired university researchers at $t-2$. However, we found a positive effect, indicating that the ability to utilize these potentially valuable sources of knowledge, skills, and techniques needs to be learnt through a laborious and painstaking process.

Finally, we contribute to the literature on university-industry interactions. We show that the transfer of knowledge between universities and private business firms is not confined to formal research cooperation and joint research projects, the assumption in much of the literature. Publicprivate transfer of knowledge is also achieved through mobility of university researchers and hiring of recent graduates, which we show have sizeable economic and statistically highly significant effects on the innovative activity of private firms.

The findings from this study have implications for managerial practice. For example, the contribution of R\&D stayers is small in both absolute and relative terms, which suggests that firms need to devise strategies to keep their worker stock up-to-date with science and engineering developments. This might include initiatives to facilitate exchanges of knowledge between academia and industry. Hiring from academia should of course reduce the adverse effects of knowledge decay, prompting the question of why industry does not recruit more from 
universities, especially given our finding that the direct contribution to patenting activity of stayers is much lower than that of mobile workers. We would suggest that the reason might be related to "endogenous absorptive capacity" (Arora \& Gambardella, 1990; Cockburn \& Henderson, 1998; Cohen \& Levinthal, 1990; Zahra \& George, 2002). Certainly, our results suggest that absorptive capacity is crucially important in this context: firms with no prior experience of hiring university researchers may find it difficult to integrate them into their knowledge production.

This study has some limitations. As already noted, we model only one particular antecedent to absorptive capacity: previous experience of hiring and integrating university researchers. While this approach has advantages in our context, future research could model more facets of the notion of absorptive capacity. Also, Fleming and Sorenson (2004) suggest that scientific thinking for performing technological search is more important when technologies are tightly coupled. We need to investigate whether hiring university scientists is more beneficial for firm-level innovative activity in firms working with tightly coupled technologies compared to firms engaged in less closely connected technologies. Insights from this research could inform management decisions about R\&D worker recruitment, and the types of workers that would bring the most benefits.

\section{REFERENCES}

Agarwal, R., Echambadi, R., Franco, A., \& Sarkar, M. B. 2004. Knowledge transfer through inheritance: Spin-out generation, development, and survival. Academy of Management Journal, 47(4): 501-522.

Agarwal, R., \& Ohyama, A. 2012. Industry or academia, basic or applied? Career choices and earnings trajectories of scientists. Management Science, Published online before print October 8, 2012.

Almeida, P., \& Kogut, B. 1999. Localization of knowledge and the mobility of engineers in regional networks. Management Science, 45(7): 905-917. 
Arora, A., \& Gambardella, A. 1990. Complementarities and external linkages: The strategies of the large firms in biotechnology. The Journal of Industrial Economics, 38(4): 361-379.

Arundel, A., \& Kabla, I. 1998. What percentage of innovations are patented? Empirical estimates for european firms. Research Policy, 27: 127-141.

Barney, J. B. 1991. Firm resources and sustained competitive advantage Journal of Management, 17(1): 99-120.

Belsley, D. A., Kuh, E., \& Welsch, R. E. 1980. Regression diagnostics: Identifying influential data and sources of collinearity. New York: Wiley.

Blundell, R., Griffith, R., \& van Reenen, J. 1995. Dynamic count data models of technological innovation. The Economic Journal, 105: 333-344.

Blundell, R., Griffith, R., \& Windmeijer, F. 2002. Individual effects and dynamics in count data models. Journal of Econometrics, 108: 113-131.

Blundell, R., Griffiths, R., \& Reenen, J. V. 1999. Market share, market value and innovation in a panel of british manufacturing firms. The Review of Economic Studies, 66(3): 529-554.

Breschi, S., Lissoni, F., \& Montobbio, F. 2008. University patenting and scientific productivity. European Management Review, 5(2): 91-109.

Cameron, A. C., \& Trivedi, P. K. 1986. Econometric models based on count data: Comparisons and applications of some estimators and tests. Journal of Applied Econometrics, 1(1): 29-53.

Campbell, B. A., Ganco, M., Franco, A., \& Agarwal, R. 2012. Who leaves, to go where, and does it matter: Employee mobility, employee entrepreneurship and the effects on parent firm performance. Strategic Management Journal, 33(1): 65-87.

Cantwell, J. 1989. Technological innovation and multinational corporations. Oxford: Blackwell.

Chesbrough, H. 2003. Open innovation. Cambridge, Massachusetts: Harvard University Press.

Cincera, M. 1997. Patents, r\&d, and technological spillovers at the firm level: Some evidence from econometric count models for panel data. Journal of Applied Econometrics, 12(3): 265280.

Cockburn, I. M., \& Henderson, R. M. 1998. Absorptive capacity, coauthoring behaviour and the organisation of research in drug discovery. Journal of Industrial Economics, XLVI(2): 157181.

Cohen, W. M., \& Levinthal, D. A. 1990. Absorptive capacity: A new perspective of learning and innovation. Administrative Science Quarterly, 35(1): 128-152. 
Corredoira, R. A., \& Rosenkopf, L. 2010. Should auld acquaintance be forgot? The reversetransfer of knowledge through mobility ties. Strategic Management Journal, 31(2): 159181.

Crépon, B., \& Duguet, E. 1997. Estimating the innovation function from patent numbers: Gmm on count panel data. Journal of Applied Econometrics, 12: 243-263.

Dahl, M. 2011. Organizational change and employee stress. Management Science, 57(2): 240256.

Dasgupta, P., \& David, P. 1994. Towards a new economics of science. Research Policy, 23(5): 487-522.

Ding, W. W. 2011. The impact of founders' professional-education background on the adoption of open science by for-profit biotechnology firms. Management Science, 57(2): 257-273

Dosi, G. 1988. The nature of the innovative process. In G. Dosi, C. Freeman, R. Nelson, G. Silverberg, \& L. Soete (Eds.), Technical change and economic theory. London: Pinter Publishers.

Fleming, L., \& Sorenson, O. 2004. Science as a map in technological search. Strategic Management Journal, 25(8-9): 909-928.

Galindo-Rueda, F., \& Haskel, J. 2005. Skills, workforce characteristics and firm-level productivity: Evidence from the matched abi/employer skills survey: IZA discussion paper No. 1542 .

Gibbons, M., \& Johnston, R. 1974. The roles of science in technological innovation. Research Policy, 3: 220-242.

Gittelman, M. 2006. National institutions, public-private knowledge flows, and innovation performance: A comparative study of the biotechnology industry in the us and france. Research Policy, 35(7): 1052-1068.

Gittelman, M. 2007. Does geography matter for science-based firms? Epistemic communities and the geography of research and patenting in biotechnology. Organization Science, 18(4): 724-741.

Gittelman, M., \& Kogut, B. 2003. Does good science lead to valuable knowledge? Biotechnology firms and the evolutionary logit of citation patterns. Management Science, 49(4): 366-382.

Griliches, Z. 1990. Patent statistics as economic indicators: A survey. Journal of Economic Literature, 28(4): 1661-1707.

Hall, B. H., Jaffe, A. B., \& Trajtenberg, M. 2005. Market value and patent citations. RAND Journal of Economics, 36(1): 16-38. 
Harhoff, D., Narin, F., Scherer, F. M., \& Vopel, K. 1999. Citation frequency and the value of patented inventions. Review of Economics and Statistics, 81(3): 511-515.

Hausman, J., Hall, B. H., \& Griliches, Z. 1984. Econometric models for count data with an application to the patents-r\&d relationship. Econometrica, 52(4): 909-938.

Helfat, C. 1994. Evolutionary trajectories in petroleum firm r\&d. Management Science, 40: 1720-1747.

Hellerstein, J. K., Neumark, D., \& Troske, K. R. 1999. Wages, productivity, and worker characteristics: Evidence from plant-level production functions and wage equations. Journal of Labor Economics, 17(3): 409-446.

Jaffe, A. 1989. Real effects of academic research. American Economic Review, 79: 957-970.

Kaiser, U., Kongsted, H. C., \& Rønde, T. 2008. Labour mobility and patenting activity. Copenhagen: Centre for Applied Microeconomics, Working Paper 2008-07.

Kaiser, U., Kongsted, H. C., \& Rønde, T. 2011. Labor mobility, social network effects, and innovative activity: IZA working paper 5654.

Kim, J., \& Marschke, G. 2005. Labor mobility of scientists, technological diffusion, and the firm's patenting decision. RAND Journal of Economics, 36(2): 298-317.

Kogut, B., \& Zander, U. 1992. Knowledge of the firm, combinative capabilities, and the replication of technology. Organization Science, 3(3): 383-397.

Lacetera, N. 2009. Different missions and commitment power in $\mathrm{r} \& \mathrm{~d}$ organizations: Theory and evidence on industry-university alliances. Organization Science, 20(3): 565-582.

Lanjouw, J., Pakes, A., \& Putnam, J. 1998. How to count patents and the value of intellectual property: The use of patent renewal and application data. Journal of Industrial Economics, 46(4): 405-432.

Laursen, K., \& Salter, A. J. 2006. Open for innovation: The role of openness in explaining innovative performance among uk manufacturing firms. Strategic Management Journal, 27(2): 131-150.

Levinthal, D., \& Rerup, C. 2006. Crossing an apparent chasm: Bridging mindful and lessmindful perspectives on organizational learning. Organization Science, 17(4): 502-513.

Levinthal, D. A., \& March, J. G. 1993. The myopia of learning. Strategic Management Journal, 14(Special issue on organizations, decision making and strategy (Winter)): 95-112.

Liebeskind, J. P. 1997. Keeping organizational secrets: Protective institutional mechanisms and their costs. Industrial and Corporate Change, 6(3): 623-663. 
Liebeskind, J. P., Oliver, A. L., Zucker, L., \& Brewer, M. 1996. Social networks, learning, and flexibility: Sourcing scientific knowledge in new biotechnology firms. Organization Science, 7(4): 428-443.

March, J. G. 1991. Exploration and exploitation in organization learning. Organization Science, 2(1): 71-87.

Metcalfe, J. S. 1994. Evolutionary economics and technology policy. Economic Journal, 104(425): 931-944.

Murray, F. 2004. The role of academic inventors in entrepreneurial firms: Sharing the laboratory life. Research Policy, 33(4): 643-659.

Nelson, R. R., \& Rosenberg, N. 1994. American universities and technical advance. Research Policy, 23(3): 323-348.

Nelson, R. R., \& Winter, S. 1982. An evolutionary theory of economic change. Cambridge, Massachusetts: Harvard University Press.

Pavitt, K. 1991. What makes basic research economically useful? Research Policy, 20: 109-119.

Pavitt, K. L. R. 1988. International patterns of technological accumulation. In N. Hood, \& J. E. Vahlne (Eds.), Strategies in global competetion. London: Croom Helm.

Penrose, E. T. 1959. The theory of the growth of the firm. Oxford: Basil Blackwell.

Roach, M., \& Sauermann, H. 2010. A taste for science? Phd scientists' academic orientation and self-selection into research careers in industry. Research Policy, 39: 422-434.

Rosenberg, N. 1990. Why do firms do basic research (with their own money)? Research Policy, 19(2): 165-174.

Rosenkopf, L., \& Almeida, P. 2003. Overcoming local search through alliances and mobility. Management Science, 49(6): 751-766.

Rosenkopf, L., \& Nerkar, A. 2001. Beyond local research: Boundary-spanning, exploration, and impact in the optical disk industry. Strategic Management Journal, 22(4): 287-306.

Rothaermel, F., \& Alexandre, M. 2009. Ambidexterity in technology sourcing: The moderating role of absorptive capacity. Organization Science, 20(4): 759-780.

Rothwell, R., Freeman, C., Jervis, P., Robertson, A., \& Townsend, J. 1974. Sappho updated project sappho phase 2. Research Policy, 3(3): 258-291.

Salter, A., \& Martin, B. R. 2001. The economic benefits of publicly funded basic research: A critical review. Research Policy, 30(3): 509-532.

Sauermann, H., \& Stephan, P. 2012. Conflicting logics? A multidimensional view of industrial and academic science. Organization Science, Published online before print September 10, 2012. 
Schumpeter, J. A. 1912/1934. The theory of economic development: An inquiry into profits, capital, credit, interest and the business cycle (R. Opie, Trans.). London: Oxford University Press.

Singh, J., \& Agrawal, A. 2011. Recruiting for ideas: How firms exploit the prior inventions of new hires. Management Science, 57(1): 129-150.

Smith, A. 1976. An inquiry into the nature and causes of the wealth of nations. Oxford: Clarendon.

Song, J., Almeida, P., \& Wu, G. 2003. Learning-by-hiring: When is mobility more likely to facilitate inter-firm knowledge transfer? Management Science, 49(4): 351-365.

Sørensen, J. B. 2007. Bureaucracy and entrepreneurship: Workplace effects on entrepreneurial entry. Administrative Science Quarterly, 52(3): 387-412.

Spencer, J. W. 2001. How relevant is university-based scientific research to private hightechnology firms? A united states-japan comparison. Academy of Management Journal, 44(2): 432-440.

Stern, S. 2004. Do scientists pay to be scientists? Management Science, 50 (6): 835-853.

Stuart, T., \& Podolny, J. 1996. Local search and the evolution of technological capabilities. Strategic Management Journal, 17(Special Issue: evolutionary perspectives on strategy (Summer)): 21-38.

Szulanski, G. 1996. Exploiting internal stickiness: Impediments to the transfer of best practice. Strategic Management Journal, 17(Special issue on knowledge and the firm (Winter)): 27-43.

Trajtenberg, M. 1990. A penny for your quotes: Patent citations and the value of innovations. RAND Journal of Economics, 21: 172-187.

Tripsas, M., \& Gavetti, G. 2000. Capabilities, cognition, and inertia: Evidence from digital imaging. Strategic Management Journal, 21(10/11): 1147-1161.

Tzabbar, D. 2009. When does scientist recruitment affect technological repositioning? Academy of Management Journal, 52(5): 873-896.

Webb, C., Dernis, H., Harhoff, D., \& Hoisl, K. 2005. Analysing european and international patent citations: A set of epo patent database building blocks. STI Working Paper, OECD: 2005/2009.

Winkelmann, R. 2008. Econometric analysis of count data. New York: Springer.

Zahra, S. A., \& George, G. 2002. Absorptive capacity: A review, reconceptualization, and extension. Academy of Management Review, 27(2): 185-203. 
TABLE 1

Descriptive Statistics

\begin{tabular}{|c|c|c|c|c|c|c|}
\hline & \multicolumn{2}{|c|}{ All obs. } & \multicolumn{2}{|c|}{$\begin{array}{l}\text { Obs. w/o pre- } \\
\text { sample patent }\end{array}$} & \multicolumn{2}{|c|}{$\begin{array}{l}\text { Obs. w/ pre- } \\
\text { sample patent }\end{array}$} \\
\hline & Mean & $\begin{array}{l}\text { Std. } \\
\text { dev. }\end{array}$ & Mean & $\begin{array}{l}\text { Std. } \\
\text { dev. }\end{array}$ & Mean & Std. dev. \\
\hline \# Patent applications, citations weighted & 0.294 & 4.375 & 0.060 & 1.653 & 2.239 & 12.282 \\
\hline \# Patent applications, citations unweighted & 0.115 & 0.267 & 0.117 & 0.272 & 0.101 & 0.218 \\
\hline Joiners from firms & 0.115 & 0.267 & 0.117 & 0.272 & 0.101 & 0.218 \\
\hline Other joiners & 0.008 & 0.072 & 0.008 & 0.073 & 0.012 & 0.065 \\
\hline Recent graduate joiners & 0.044 & 0.178 & 0.046 & 0.184 & 0.023 & 0.111 \\
\hline Joiners from universities & 0.040 & 0.160 & 0.041 & 0.165 & 0.035 & 0.113 \\
\hline R\&D support workers & 0.161 & 0.331 & 0.157 & 0.332 & 0.192 & 0.318 \\
\hline $\ln$ (capital stock) at t-1 & 15.170 & 2.845 & 14.890 & 2.744 & 17.493 & 2.586 \\
\hline $\ln (\mathrm{R} \& \mathrm{D}$ workers $)$ at $\mathrm{t}-1$ & 0.790 & 1.079 & 0.703 & 0.980 & 1.516 & 1.503 \\
\hline Previous cooperation (dummy) & 0.011 & --- & 0.002 & --- & 0.083 & --- \\
\hline Previous coop. with public sector (dummy) & 0.001 & --- & 0.000 & --- & 0.005 & --- \\
\hline $\ln ($ adj. \# patents in 1990 , citations weighted) & -11.119 & 1.228 & --- & --- & -7.855 & 1.434 \\
\hline $\ln (\operatorname{adj} . \#$ patents in 1990) & -11.094 & 1.271 & --- & --- & -7.624 & 1.229 \\
\hline Patent at t-1 (dummy) & 0.039 & 0.194 & 0.010 & 0.098 & 0.284 & 0.451 \\
\hline Positive patent stock in 1990 (dummy) & 0.108 & --- & 0.000 & --- & 1.000 & --- \\
\hline \# obs. & 16,531 & & 14,750 & & 1,781 & \\
\hline
\end{tabular}

Note: Descriptive statistics for the entire set of observations, for observations of firms with pre-sample patents and those with no pre-sample patents. 
TABLE 2

Correlations

\begin{tabular}{|c|c|c|c|c|c|c|c|c|c|c|c|c|}
\hline & & 1. & 2. & 3 & 4. & 5. & 6. & 7. & 8. & 9. & 10. & 11. \\
\hline 1. & \# Patent applications, citations weighted & & & & & & & & & & & \\
\hline 2. & Joiners from firms & 0.006 & & & & & & & & & & \\
\hline 3 & Recent graduate joiners & 0.027 & -0.025 & & & & & & & & & \\
\hline 4. & Other joiners & -0.022 & -0.076 & -0.020 & & & & & & & & \\
\hline 5. & Joiners from universities & 0.010 & -0.068 & -0.001 & -0.039 & & & & & & & \\
\hline 6. & R\&D support workers & -0.002 & -0.162 & -0.045 & -0.101 & -0.103 & & & & & & \\
\hline 7. & $\ln ($ capital stock) & 0.207 & -0.010 & -0.019 & -0.061 & -0.042 & 0.168 & & & & & \\
\hline 8. & $\ln (\mathrm{R} \& \mathrm{D}$ workers $)$ & 0.264 & -0.032 & 0.002 & -0.060 & 0.003 & -0.021 & 0.337 & & & & \\
\hline 9. & $\ln (\operatorname{adj} . \#$ patents in 1990, citations weighted $)$ & 0.524 & -0.016 & 0.019 & -0.036 & -0.009 & 0.017 & 0.295 & 0.303 & & & \\
\hline 10. & Previous cooperation & 0.438 & -0.019 & 0.020 & -0.040 & -0.013 & 0.032 & 0.284 & 0.230 & 0.924 & & \\
\hline 11. & Previous coop. with public sector & 0.225 & -0.009 & 0.019 & -0.010 & -0.004 & -0.018 & 0.108 & 0.188 & 0.324 & 0.243 & \\
\hline 12. & Positive patent stock in 1990 & 0.026 & -0.003 & 0.004 & -0.004 & 0.001 & -0.007 & 0.004 & 0.023 & 0.051 & 0.050 & 0.017 \\
\hline
\end{tabular}

Note: The specification includes sector, year and region dummies. For reasons of space, the correlations are not displayed here. 
TABLE 3

Main Estimation Results

\begin{tabular}{|c|c|c|c|c|c|c|}
\hline \multirow{2}{*}{ Labor type shares (base: $\mathrm{R} \& D$ stayers) at $t-1$} & \multicolumn{3}{|c|}{$\begin{array}{c}\text { Model I } \\
\text { W/o interactions }\end{array}$} & \multicolumn{3}{|c|}{$\begin{array}{c}\text { Model II } \\
\text { W/ interactions }\end{array}$} \\
\hline & Coeff. & \multicolumn{2}{|c|}{ Std. Err. } & Coeff. & \multicolumn{2}{|c|}{ Std. Err. } \\
\hline Joiners from firms & 0.789 & 0.196 & $* *$ & 0.953 & 0.320 & $* *$ \\
\hline Recent graduate joiners & 0.843 & 0.315 & $* *$ & 0.630 & 0.822 & \\
\hline Other joiners & 0.226 & 0.396 & & -0.603 & 0.719 & \\
\hline Joiners from universities & 1.909 & 0.516 & $* *$ & 0.219 & 1.268 & \\
\hline R\&D Support workers & 0.298 & 0.207 & & 0.273 & 0.238 & \\
\hline \multicolumn{7}{|l|}{ Interactions } \\
\hline Hired uni.res. at $t-2 *$ joiners from universities at $t-1$ & --- & --- & & 4.112 & 2.115 & $*$ \\
\hline Hired uni.res. at $\mathrm{t}-2 *$ grad. joiners at $t-1$ & --- & --- & & 2.698 & 1.269 & $*$ \\
\hline Hired uni. res. at $t-2$ & --- & --- & & 0.097 & 0.190 & \\
\hline \multicolumn{7}{|l|}{ Other innovative inputs } \\
\hline $\ln$ (capital stock) & 0.175 & 0.033 & $* *$ & 0.171 & 0.040 & $* *$ \\
\hline $\ln (\mathrm{R} \& \mathrm{D}$ workers $)$ & 0.232 & 0.056 & $* *$ & 0.188 & 0.068 & $* *$ \\
\hline \multicolumn{7}{|l|}{ Controls for previous co-patenting } \\
\hline Previous cooperation & 0.294 & 0.162 & $\dagger$ & 0.500 & 0.374 & \\
\hline Previous cooperation with public sector & -0.109 & 0.504 & & 0.349 & 0.175 & $*$ \\
\hline \multicolumn{7}{|l|}{ State dependence \& dynamics } \\
\hline Patent at t-1 & 1.405 & 0.168 & $* *$ & 1.464 & 0.192 & $* *$ \\
\hline $\ln$ (adj. \# patents in 1990, citations weighted) & 0.318 & 0.076 & $* *$ & 0.287 & 0.090 & $* *$ \\
\hline Positive patent stock in 1990 & 0.293 & 0.280 & & 0.500 & 0.374 & \\
\hline \multicolumn{7}{|l|}{ \# obs. \& \# unique firms } \\
\hline \# obs. & 16,531 & & & 10,585 & & \\
\hline \# unique firms & 5,714 & & & 3,880 & & \\
\hline
\end{tabular}

Note: The dependent variable is the number of the firm's citations-weighted patent applications per year. The estimation results are generated by Pre Sample Mean Estimation. Our specification also includes year, sector and region dummy variables.

$\dagger p<.10$

* $p<.05$

$* * p<.01$

Two-tailed tests for controls, one-tailed tests for hypothesized variables. 
TABLE 4

Hypotheses Tests

\begin{tabular}{ccc}
\hline \hline Model I & Model II \\
\hline W/o interactions & W/ interactions \\
$\chi^{2}$ dof & $\chi^{2}$ dof
\end{tabular}

H1: firm joiners contribute more to innovative activity than stayers.

$\begin{array}{lllllll}\text { H1a - Joiners from firms vs. stayers: } & 16.28 & 1 & * * & 8.88 & 1 & * * \\ \text { H1b - Recent graduates vs. stayers: } & 7.15 & 1 & * * & 0.59 & 1 & \\ \text { H1c - Joiners from universities vs. stayers: } & 13.68 & 1 & * * & 0.03 & 1 & \\ \text { H1 joint: } & 29.24 & 3 & * * & 9.07 & 3 & * *\end{array}$

H2: Newly hired university researchers give a stronger contribution to innovative activity than recently hired recent graduates or joiners from firms.
$\mathrm{H} 2 \mathrm{a}$ - Recent graduates:
$\begin{array}{lllll}4.56 & 1 & * * & 0.32 & 1\end{array}$
$\mathrm{H} 2 \mathrm{~b}$ - Joiners from firms:
$3.28 \quad 1 * 0.07 \quad 1$
H2 Joint:
$4.56 \quad 2 * 0.48 \quad 2$

H3: Firms' recent experience in hiring university researchers enhances the effect of newly hired university researchers' contribution to innovative activity.

$$
\text { -- }---\quad 3.78 \quad 1 *
$$

H4: Firms' recent experience in hiring university researchers enhances the effect of newly hired recent graduates' contribution to innovative activity.

\begin{tabular}{llll}
--- & -- & 4.52 & $1^{* *}$ \\
\hline
\end{tabular}

Note: " $\chi 2$ " corresponds to a Wald test for (joint) significance. The test results are based on the estimation results displayed in Table 2. "dof" denote the degrees of freedom underlying the test.

$\dagger \quad p<.10$

$* \quad p<.05$

$* * \quad p<.01$

One-tailed tests. 
TABLE 5

Marginal Effects at Means

\begin{tabular}{|c|c|c|c|c|c|c|c|c|}
\hline & \multicolumn{2}{|c|}{ All obs. } & \multicolumn{4}{|c|}{$\begin{array}{cc} & \text { Firms w/ at least } \\
\text { Firms w/ at least } & \text { one pre-sample } \\
\text { one patent } & \text { patent }\end{array}$} & \multicolumn{2}{|c|}{$\begin{array}{l}\text { Average firm w/ } \\
\text { one patent }\end{array}$} \\
\hline & ME & $p$-val. & ME & $p$-val. & ME & $p$-val. & ME & $p$-val. \\
\hline \multicolumn{9}{|c|}{ Specification w/o interaction with past hires of university researchers (Model I) } \\
\hline Joiners from firms & 0.036 & 0.000 & 0.145 & 0.000 & 0.087 & 0.000 & 0.124 & 0.000 \\
\hline Recent graduate joiners & 0.039 & 0.003 & 0.155 & 0.003 & 0.092 & 0.002 & 0.132 & 0.003 \\
\hline Other joiners & 0.011 & 0.484 & 0.043 & 0.527 & 0.028 & 0.473 & 0.039 & 0.484 \\
\hline Joiners from universities & 0.086 & 0.000 & 0.348 & 0.000 & 0.204 & 0.000 & 0.291 & 0.000 \\
\hline R\&D support workers & 0.015 & 0.044 & 0.056 & 0.058 & 0.035 & 0.037 & 0.050 & 0.044 \\
\hline Stayers & 0.001 & 0.558 & 0.002 & 0.816 & 0.004 & 0.366 & 0.004 & 0.558 \\
\hline \multicolumn{9}{|c|}{ Specification w/o interaction with past hires of university researchers (Model II) } \\
\hline \multicolumn{9}{|c|}{ Firms with university graduate hire in $t-2$} \\
\hline Joiners from firms & 0.039 & 0.012 & 0.141 & 0.022 & 0.088 & 0.015 & 0.106 & 0.012 \\
\hline Recent graduate joiners & 0.150 & 0.002 & 0.589 & 0.002 & 0.345 & 0.002 & 0.406 & 0.002 \\
\hline Other joiners & -0.033 & 0.323 & -0.153 & 0.262 & -0.080 & 0.305 & -0.090 & 0.323 \\
\hline Joiners from universities & 0.197 & 0.016 & 0.778 & 0.018 & 0.454 & 0.016 & 0.533 & 0.016 \\
\hline R\&D support workers & 0.008 & 0.532 & 0.013 & 0.795 & 0.015 & 0.602 & 0.021 & 0.532 \\
\hline Stayers & -0.005 & 0.558 & -0.039 & 0.265 & -0.015 & 0.462 & -0.014 & 0.558 \\
\hline \multicolumn{9}{|c|}{ Firms without university graduate hire in $t-2$} \\
\hline Joiners from firms & 0.048 & 0.000 & 0.187 & 0.001 & 0.110 & 0.001 & 0.130 & 0.012 \\
\hline Recent graduate joiners & 0.033 & 0.377 & 0.126 & 0.396 & 0.075 & 0.383 & 0.089 & 0.002 \\
\hline Other joiners & -0.025 & 0.455 & -0.106 & 0.426 & -0.058 & 0.448 & -0.067 & 0.323 \\
\hline Joiners from universities & 0.014 & 0.815 & 0.049 & 0.837 & 0.031 & 0.821 & 0.037 & 0.016 \\
\hline $\mathrm{R} \& \mathrm{D}$ support workers & 0.016 & 0.076 & 0.059 & 0.113 & 0.037 & 0.085 & 0.044 & 0.532 \\
\hline Stayers & 0.004 & 0.174 & 0.007 & 0.552 & 0.007 & 0.252 & 0.010 & 0.558 \\
\hline
\end{tabular}

Note: Based on the estimation results in Table 2. The top panel refers to the specification without interactions with the dummy variable for past university hires, the two lower panels refer to the specification with interactions included. Marginal effects are evaluated at the means of the involved variables. E.g., 1 additional joiner from a private firm is related to 0.039 additional citations-weighted patents for the firms in the specification with no past university hires interactions. 